Mariia FEDORUK, Lyudmyla ZAHVOYSKA

\title{
MODELING THE PROCESS \\ OF ECOLOGIZATION INVESTMENTS \\ IN ENERGY SAVING IN RESIDENTIAL \\ AND PUBLIC BUILDINGS \\ OF CITIES BY USING THE METHOD \\ OF SYSTEM DYNAMICS
}

\begin{abstract}
Using the method of system dynamics, hypotheses about functioning of the mechanism of energy saving stimulation in buildings and its ecologization tools have been proposed and tested. The results of the survey conducted by domestic and foreign experts were used as the main empirical data for analysis and modeling. The constructed simulation models have allowed to prove the advisability of using multicriteria assessment of energy saving measures effectiveness, as well as to test the recommendations we propose concerning ecologization of the energy saving process by integrating environmental and social assessments into the rules for making investment decisions. Methods of system dynamics revealed undesirable consequences and points of resistance, which can cause the failure of the proposed intervention.
\end{abstract}

(C) Mariia Fedoruk, Lyudmyla Zahvoyska, 2018.

Fedoruk Mariia, MSc, Teaching Assistant, Vasyl Stefanyk Precarpathian National University Zahvoyska Lyudmyla, PhD, Associate Professor, UNFU, Lviv, Ukraine. 


\section{Key words:}

Ecological measures of thermo-modernization, simulation modeling, investments in energy saving, the mechanism of stimulation, system dynamics.

JEL: Q57.

\section{Problem formulation}

The success or failure of the state energy policy can be measured by the volume of investments in energy saving.

According to the calculations of experts as much as 95 billion euro must be invested just to renovate Ukrainian multi-apartment housing stock (about 19 million dwellings). (GIZ, 2010), According to the «Energy Efficiency Program in Ukraine -EE4U», within the next five years (2018-2022), 8.5 billion hryvnyas (268 million euro according to the agreement) will be spent on the implementation of energy-efficient measures in the housing sector of Ukraine. Ukraine is expected to contribute 6.5 billion hryvnyas, 1.5 billion hryvnyas will be contribted by the European Union and 0.5 billion hryvnyas by the German government. However, even with the support of other countries and international funds, investments in energy-saving measures are insufficient. Therefore, the long-term goal should be to attract the private sector in such a way that the energy-saving market becomes self-sufficient.

Any change of the established mechanisms involves complex, interconnected processes characterized by multiple and reciprocal interactions, nonlinear dynamics, and time and space distances caused by causation. So, the structural analysis of the studied socioeconomic system will help provide data for studying, discussing and, therefore, a better understanding of ways to improve the investment mechanism in energy saving, which will determine the points of high level impact for effective interference in the analyzed processes.

There are several means that can help visualize the interconnection of system components like high-level system frameworks, maps of actor networks, subsystem diagrams, stock and flow maps (Holtz et al., 2015). For our analysis, it was necessary to select a method that not only helps identify the main levers of influence, but also undesirable consequences and points of resistance that may 
lead to the failure of the proposed intervention. Therefore, in order to understand what changes are needed to improve the mechanism of investing in energy saving in Ukrainian buildings and how exactly these interventions will affect the system as a whole, the system dynamics method has been used.

\section{Analysis of recent studies and publications}

Great attention to the issues of energy saving and financing of ESM has been paid by the following scientists: V. Volkov, G. Kopets, A. Petrova, R. Tormosov, V. Chevganov and others (Volkov, 2014; Kopets 2009; Tormosov, 2010; Chevganova \& Petrova, 2014). From the position of state regulation, the problem of energy saving measures implementation was studied by such scientists as S. Denysyuk, O. Sukhodolya, T. Taukesheva (Denysiuk, 2013; Taukesheva 2015, Cukhudolya, 2015). On the level of housing and utilities enterprises, investments in energy saving were considered by N. Hetalo and V. Titiaev (Titiaev \& Getalo, 2012). The specificity of energy efficiency state policy in Ukraine from the perspective of the population was investigated by N. Smentyna (Smentyna, 2016).

Along with this, the complex structural analysis of ESM stimulation mechanism as an ecological and economic system has not been studied thoroughly enough to take into account the environmental impacts of these measures.Therefore, in this article we investigate the relationship between the elements of the system, as well as identify the main levers of influence and reveal undesirable consequences and points of resistance, for a deep understanding of the ways of Ecologization the mechanism of investment in energy saving.

\section{Methods and materials of research}

System dynamics is a methodology developed on the basis of simulation modeling for the analysis of nonlinear behavior of complex systems by studying the interaction of their elements. The method was developed in the mid-1950s by Professor Jay Forrester of the Massachusetts Institute of Technology (J. Forrester, 1971).

Perhaps the best-known example of system dynamics application is the study published in the book "Limits to Growth» (D. H. Meadows, Meadows, Randers, \& Behrens, 1972). With this method, any complex problem or system (for example, ecosystem, political system or mechanical system) can be represented as a causal diagram (Sterman, 2000). The structural interaction of dy- 
namic variables allows the formation of loops of feedback, amplifying or balancing, that is, to detect and evaluate the effects of endogenous feedback between the variables of the system. Besides it enables the inclusion of nonlinear relationships between elements of the system (Farina, 2014; J. W. Forrester, 1992).

Causal loop diagram (CLD) is a reflection of the studied system with all its constituents and their interaction. By recreating the structure, an analyst gets the opportunity to investigate the system's behavior over a period of time (Donella $\mathrm{H}$. Meadows, 2008). CLD help visualize the structure and behavior of the system and analyze it using qualitative data. CLD are used in a variety of areas, including environmental economy (Van den Belt et al., 2010; Videira et al., 2014) and bio-based economy (Bennich, Belyazid, Kopainsky, \& Diemer, 2018). These models reflect hypotheses regarding the structure of the system. Initially, they were used to demonstrate formal simulation models or as a transitional phase between the conceptualization and the development of a quantitative model (Lane, 2008). However, CLD can also be used as an independent analytical tool. In addition to visualizing the structure of the system on the basis of hypotheses, the approach allows to outline problem areas, formulate topics for further research, identify areas of risk and uncertainty (Stave \& Kopainsky, 2015). Flow Diagrams are used to perform quantitative analysis of complex systems (Bennich et al., 2018). These charts use three types of variables: stocks (drives), flows, and dynamic variables - to reflect the accumulation and instant causative relationships. In addition, it is possible to use parameters whose values do not change under the influence of other elements of the system or time. Such models are usually built and implemented by means of computer software (Sterman, 2000).

Today, there is a great variety of software that can be used to build a simulation model: in particular, Vensim, STELLA, AnyLogic, etc. One of the most versatile programs is AnyLogic, which combines several approaches to discrete (event modeling) and continuous imitation simulation on a single platform: system dynamics, flowcharts, multi-agent simulation, and more. (Sokolovska \& Klepikova, 2015).

Experts' interviews were used as the main empirical data for constructing CLD namely, "Obstacles and Incentives for the Introduction of ESM in Europe», as well as «SWOT-analysis of Energy Saving Policies in Residential and Public Buildings» (Fedoruk \& Zahvoyska, 2016). 


\section{Empirical study and results}

The simulation model of the ecologization process for investing in energy saving in residential and public buildings of cities, taking into account the assessment of their ecological and economic efficiency, was developed using the SD method based on the CLD (Figure 1) with the help of AnyLogic software.

Figure 1

The simulation model of the ecologization process for investing in energy saving in residential and public buildings of cities.

Developed by the authors

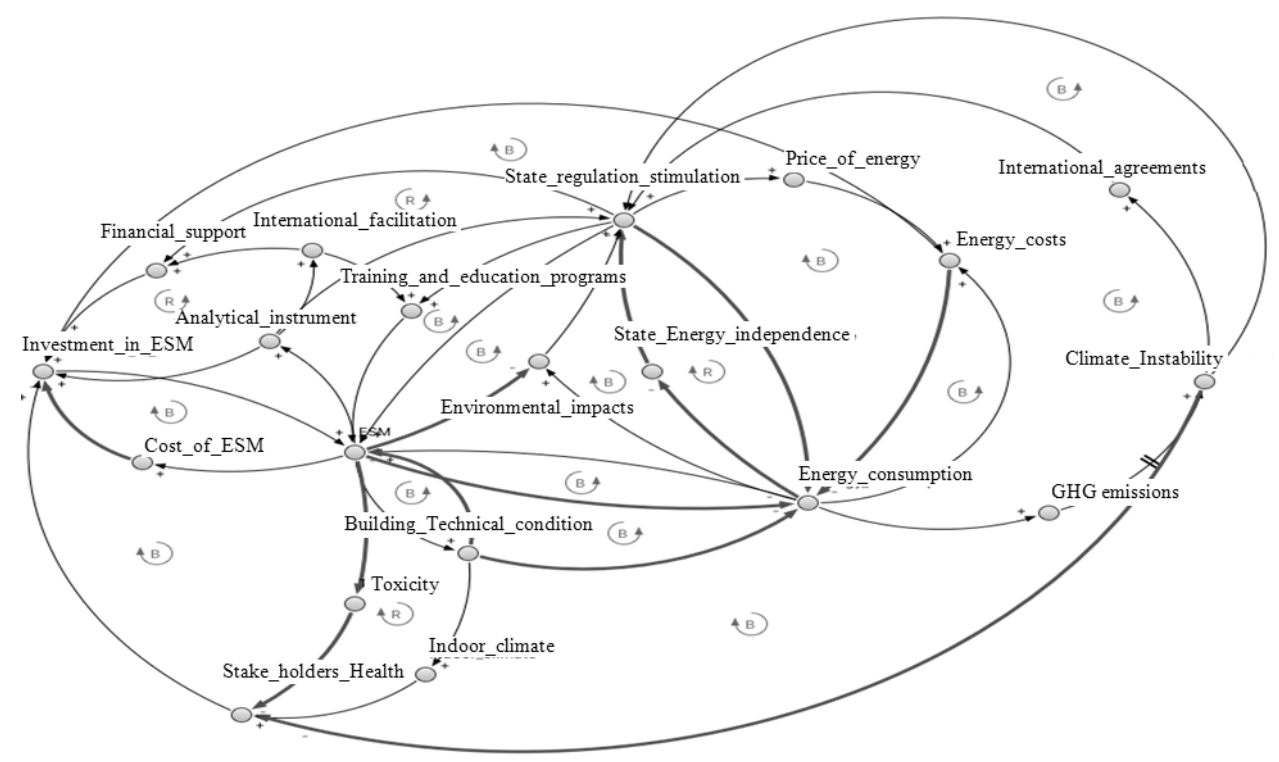

The simulation model we have constructed (Fig. 1) consists of 20 dynamic variables that affect each other through positive and negative feedback, which form balancing (B) and amplifying loops (R) feedback. The causal relationship indicated by the «+» symbol reflects the positive (amplifying) effect of one element of the system on the other in accordance with the direction of the arrow. Such feedback can lead to uncontrolled exponential growth and, ultimately, to the 
transition to a new state of the system. Meanwhile the causal relationship marked with the symbol «-» reflects the negative, balancing effect of one component of the system to another in accordance with the direction of the arrow. As a result, it leads the system to its original state.

According to the results of our previous study «Obstacles and Incentives for the Introduction of ESM in Europe", the use of ecological and economic efficiency indicators for evaluating and stimulating the introduction of ESM in residential and public buildings is one of the proposed ways for improvement the mechanism of energy saving ecologization. For example, to indemnify investment costs only for those projects that proved to be effective in accordance with the environmental, economic, social and technical criteria based on the results of multicriteria analysis (Zahvoyska, L. D. \& Fedoruk M. I., 2017). On the basis of expert responses, another proposal was made to change the mechanism of stimulation of energy saving measures. Namely, it is necessary to integrate the indicators of socio-ecological and economic efficiency (based on the results of the assessment of the entire ESM life cycle into the tool of state regulation and to strengthen the control over the quality of implementation of these measures.

The third proposed change of experts in the mechanism of environmental protection measures is to provide training and knowledge dissemination about the impact of materials and technologies used for thermo-modernization which would be accessible to all key participants in the research process. According to experts, the fourth important change in the process of energy saving ecologization is the improvement of the energy accounting system, norms of energy consumption and greenhouse gas emissions. The influence of these interventions in the system was tested with the help of «What If» questions using the CLD (Fig. 1). Modeling results are shown in Table 1.

Table1 provides a brief description of the desired results and suggested measures to avoid the potential undesirable effects. Besides it represents additional levels of influence as well as uncertainties and questions that remain for further research. The final analysis is limited by the proposals and factors obtained through modeling.

As the study results show, there are numerous levers of influence and ways in which the energy saving policy can promote stimulation of the ESM ecologization with the greatest benefit to the investor, society and the environment. There is a great potential for the development of effective and consistent packages of proposals for the ESM implementation. On the other hand, the process of simultaneous implementation of numerous changes requires a systematic approach to prioritization. 
Table 1

Summary review of proposed measures for ecologization investments in energy saving in residential and public buildings

\begin{tabular}{|c|c|c|c|c|}
\hline $\begin{array}{l}\text { Questions } \\
\text { for testing } \\
\text { recommended } \\
\text { activities }\end{array}$ & $\begin{array}{l}\text { The desired } \\
\text { result }\end{array}$ & $\begin{array}{l}\text { Potential } \\
\text { undesirable } \\
\text { effects }\end{array}$ & $\begin{array}{l}\text { Additional } \\
\text { levers } \\
\text { of influence }\end{array}$ & $\begin{array}{l}\text { Uncertainties } \\
\text { and examples } \\
\text { of related } \\
\text { questions }\end{array}$ \\
\hline \multicolumn{5}{|c|}{$\begin{array}{c}\text { Recommendation } 1 . \\
\text { Integrate the indicators of socio-ecological and economic efficiency into the tools } \\
\text { for of ESM assessment and stimulation }\end{array}$} \\
\hline $\begin{array}{l}\text { 1. What will be } \\
\text { the benefit of } \\
\text { intergratng in- } \\
\text { dicators of } \\
\text { socio- } \\
\text { ecological and } \\
\text { economic effi- } \\
\text { ciency into } \\
\text { tools for pro- } \\
\text { moting energy } \\
\text { saving in resi- } \\
\text { dential and } \\
\text { public build- } \\
\text { ings? }\end{array}$ & $\begin{array}{l}\text { Increase of } \\
\text { investments in } \\
\text { the ESM, with } \\
\text { the greatest } \\
\text { benefit to the } \\
\text { investor, } \\
\text { society and the } \\
\text { environment }\end{array}$ & $\begin{array}{l}\text { - Saving energy } \\
\text { can cause an } \\
\text { increase in its } \\
\text { volumes In the } \\
\text { situation of } \\
\text { economic and } \\
\text { political } \\
\text { instability and } \\
\text { lack of } \\
\text { confidence in } \\
\text { the authorities, } \\
\text { rapid growth of } \\
\text { investment will } \\
\text { not happen }\end{array}$ & $\begin{array}{l}\text { - Price } \\
\text { regulation } \\
\text { (higher prices } \\
\text { for energy sup- } \\
\text { ply will cause } \\
\text { an increase in } \\
\text { investment } \\
\text { volume) } \\
\text { - State support } \\
\text { International } \\
\text { financial and } \\
\text { information } \\
\text { support }\end{array}$ & $\begin{array}{l}\text { - How will an } \\
\text { investor } \\
\text { respond to an } \\
\text { increase in the } \\
\text { cost of the en- } \\
\text { ergy supply? } \\
\text { - What should } \\
\text { be the financial } \\
\text { support of } \\
\text { investment by } \\
\text { the state? } \\
\text { - Will it pro- } \\
\text { mote the } \\
\text { development of } \\
\text { the energy } \\
\text { services market } \\
\text { and } \\
\text { commercial } \\
\text { investments? }\end{array}$ \\
\hline \multicolumn{5}{|c|}{$\begin{array}{c}\text { Recommendation } 2 . \\
\begin{array}{c}\text { Integrate indicators of socio-ecological and economic efficiency into tools of state } \\
\text { regulation and quality control of the ESM implementation }\end{array}\end{array}$} \\
\hline $\begin{array}{l}\text { 2. What will be } \\
\text { the benefit of } \\
\text { intergratng in- } \\
\text { dicators of } \\
\text { socio- } \\
\text { ecological and } \\
\text { economic effi- } \\
\text { ciency into } \\
\text { tools of state } \\
\text { regulation and } \\
\text { quality control } \\
\text { of the ESM } \\
\text { implementation }\end{array}$ & $\begin{array}{l}\text { - The quality of } \\
\text { the ESM will } \\
\text { improve } \\
\text { - The negative } \\
\text { impact on the } \\
\text { environment } \\
\text { and human } \\
\text { health will } \\
\text { decrease } \\
\text { - Energy saving } \\
\text { will increase } \\
\text { - The lifetime of } \\
\text { the buildings } \\
\text { will get longer }\end{array}$ & $\begin{array}{l}\text { The cost of the } \\
\text { ESM will } \\
\text { increase and, } \\
\text { as a result, } \\
\text { The volume of } \\
\text { investments will } \\
\text { decrease }\end{array}$ & $\begin{array}{l}\text { - Technical } \\
\text { condition of the } \\
\text { building (the } \\
\text { worse the } \\
\text { building, the } \\
\text { higher the cost } \\
\text { of the ESM) } \\
\text { - Certification of } \\
\text { energy service } \\
\text { companies ser- } \\
\text { vices }\end{array}$ & $\begin{array}{l}\text { - How will the } \\
\text { eco-labeling of } \\
\text { building } \\
\text { materials and } \\
\text { ESM affect the } \\
\text { Life Cycle } \\
\text { Assessment? } \\
\text { - How will } \\
\text { certification of } \\
\text { energy service } \\
\text { companies } \\
\text { work? }\end{array}$ \\
\hline
\end{tabular}


Modeling the Process of Ecologization Investments in Energy Saving in Residential and Public Buildings of Cities by Using the Method of System Dynamics

\begin{tabular}{|c|c|c|c|c|}
\hline $\begin{array}{l}\text { Questions } \\
\text { for testing } \\
\text { recommended } \\
\text { activities }\end{array}$ & $\begin{array}{l}\text { The desired } \\
\text { result }\end{array}$ & $\begin{array}{c}\text { Potential } \\
\text { undesirable } \\
\text { effects }\end{array}$ & $\begin{array}{c}\text { Additional } \\
\text { levers } \\
\text { of influence }\end{array}$ & $\begin{array}{c}\text { Uncertainties } \\
\text { and examples } \\
\text { of related } \\
\text { questions }\end{array}$ \\
\hline \multicolumn{5}{|c|}{$\begin{array}{l}\text { Recommendation } 3 \text {. } \\
\text { eholders with training and information }\end{array}$} \\
\hline $\begin{array}{l}\text { 3. What will be } \\
\text { the benefit of } \\
\text { providing } \\
\text { stakeholders } \\
\text { with training } \\
\text { and } \\
\text { information? }\end{array}$ & $\begin{array}{l}\text { The number of } \\
\text { introduced } \\
\text { ESMs will in- } \\
\text { crease- The } \\
\text { negative impact } \\
\text { on the } \\
\text { environment } \\
\text { and human } \\
\text { health will } \\
\text { decrease- The } \\
\text { lifetime of the } \\
\text { buildings will } \\
\text { get longer }\end{array}$ & $\begin{array}{l}\text { If Itraining and } \\
\text { information are } \\
\text { of poor quality, } \\
\text { the result will } \\
\text { be the opposite } \\
\text { of the desired }\end{array}$ & $\begin{array}{l}\text { - International } \\
\text { assistance } \\
\text { (training, } \\
\text { experience } \\
\text { sharing) } \\
\text { - State support } \\
\text { (information } \\
\text { campaigns for } \\
\text { the public and } \\
\text { training of } \\
\text { contractors) }\end{array}$ & $\begin{array}{l}\text { How to improve } \\
\text { the quality of } \\
\text { training and } \\
\text { information? }\end{array}$ \\
\hline \multicolumn{5}{|c|}{$\begin{array}{c}\text { Recommendation } 4 . \\
\text { Improve the energy accounting system, norms of energy consumption and emissions } \\
\text { of greenhouse gases }\end{array}$} \\
\hline $\begin{array}{l}4 \text { What will be } \\
\text { the benefit of } \\
\text { improving the } \\
\text { energy } \\
\text { accounting } \\
\text { system, norms } \\
\text { of energy } \\
\text { consumption } \\
\text { and emissions } \\
\text { of greenhouse } \\
\text { gases? }\end{array}$ & $\begin{array}{l}\text { - Reducing risks } \\
\text { - Increase in } \\
\text { investment } \\
\text { volume } \\
\text { - Improvement } \\
\text { of the the } \\
\text { energy } \\
\text { management } \\
\text { system } \\
\text { efficiency } \\
\text { - Reducing en- } \\
\text { ergy } \\
\text { consumption } \\
\text { and emissions } \\
\text { of greenhouse } \\
\text { gases }\end{array}$ & $\begin{array}{l}\text { Incorrect } \\
\text { setting of } \\
\text { standards can } \\
\text { lead to } \\
\text { increased } \\
\text { energy } \\
\text { consumption }\end{array}$ & $\begin{array}{l}\text { - State } \\
\text { regulation } \\
\text { (establishment } \\
\text { of norms and } \\
\text { control over } \\
\text { their } \\
\text { implementation) } \\
\text { - Estimation of } \\
\text { the technical } \\
\text { condition of the } \\
\text { building } \\
\text { (energy } \\
\text { consumption } \\
\text { depends on it) } \\
\text { - Cost of } \\
\text { energy } \\
\text { consumption } \\
\text { (balancing } \\
\text { energy } \\
\text { consumption in } \\
\text { case of } \\
\text { improper } \\
\text { setting of } \\
\text { standards) }\end{array}$ & $\begin{array}{l}\text { Will the online } \\
\text { database of } \\
\text { buildings reflect } \\
\text { consumption } \\
\text { and building } \\
\text { certificates } \\
\text { increase the } \\
\text { volume and the } \\
\text { efficiency of } \\
\text { private invest- } \\
\text { ments? }\end{array}$ \\
\hline
\end{tabular}

Source: Developed by the authors. 
To confirm the reliability of the constructed CLD, we applied another system dynamics tool, namely, a Stock and flow diagram (SFD) (Bennich et al., 2018). The proposed SFD is based on the assumption that the main indicator of the efficiency of the mechanism for stimulating energy saving in buildings is the number of buildings in which the ESM have been introduced throughout the year. Accordingly, 11 other elements that are important for the adequacy of the model there heve been identified. Many other aspects are simplified and not reflected, but they are in the causal model. The constructed diagram consists of two drives (buildings without ESM and buildings with ESM), a flow (the number of buildings in which the ESM has been implemented throughout the year) and eight parameters (dynamic and constants). Due to the interaction of all these elements, two causative and consequential feedback relationships are formed: balancing and amplifying (Fig. 2). Data from the Ministry of Regional Development of Construction, Housing and Communal Services of Ukraine (MinRegion, 2016) has been used to try the model out.

\section{Figure 2}

Stock and flow diagram of the process of investing in energy saving on an example of private buildings. Developed by the authors

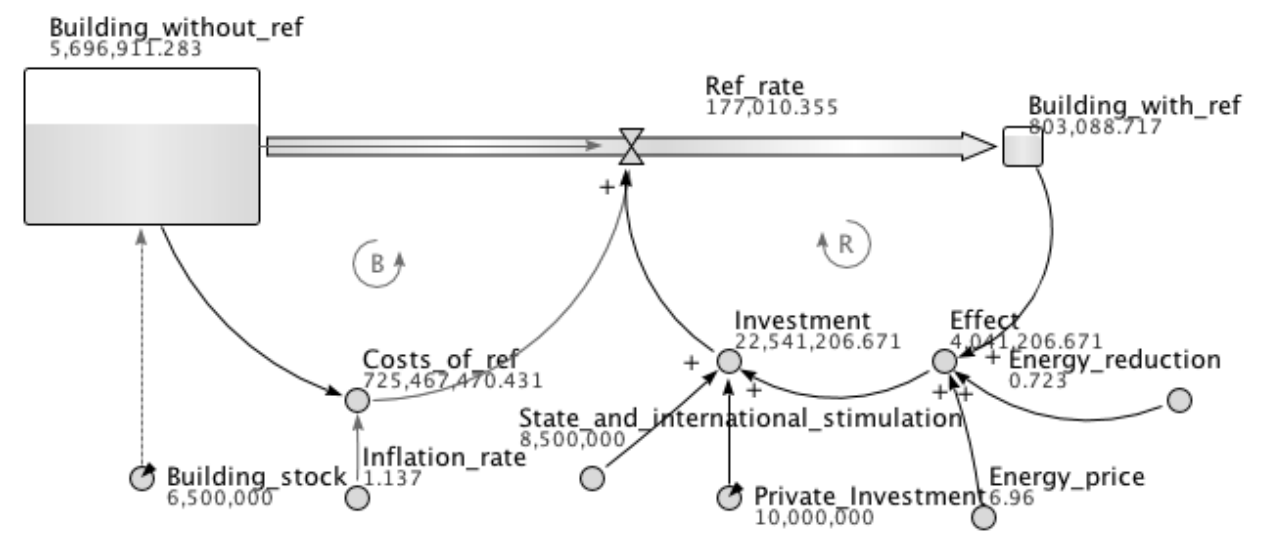

According to the assumption on which the model is based, the number of buildings in which the ESM have been introduced is greatly affected by such variables as the volume of private investments, state and international support, the ecological and economic effect of reducing energy consumption, and the cost of energy saving measures. 
The test results of the CD (Figure 3 ) confirm the correctness of the basic hypotheses regarding the functioning of the of the ESM stimulation. Mechanism stimulation. Simulated by the CLD (Fig. 1), trends in the development of processes correspond to economic realities.

Figure 3

The results of testing of model of the process of investing in energy saving on the example of private buildings

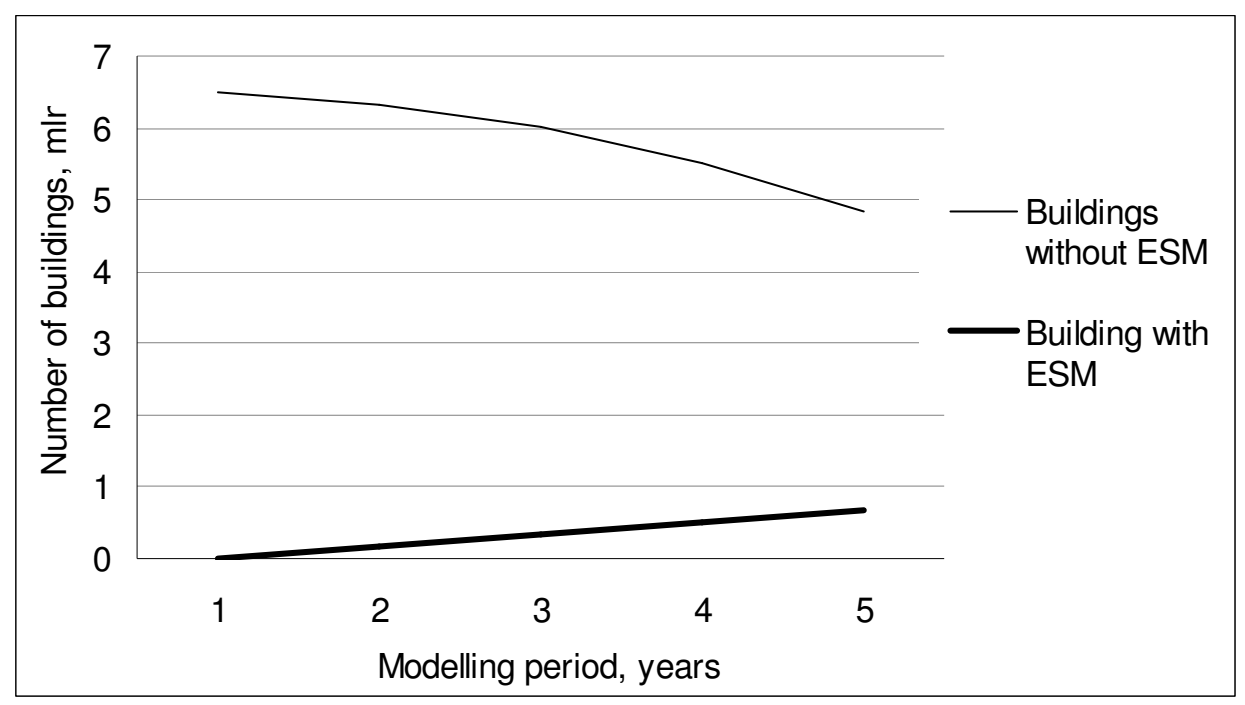

\section{Conclusions of the conducted research}

At present we are at the initial stage of the process of creating a system for stimulating and controlling the quality of energy modernization, which makes it possible to improve the mechanism of ecologizing investments in energy saving in buildings in order to obtain maximum economic benefits with minimal environmental impacts.

By means of system dynamics the mechanism of stimulation of investment in energy saving in residential and public buildings has been modeled, taking into 
account the assessment of their ecological and economic efficiency. The constructed models confirmed the necessity of using multicriteria assessment of the ESM, as well as made it possible to check the proposed recommendations regarding their ecologization of implementation.

In order to increase the positive impact on the environment and health of people from the implemented energy modernization, it is proposed to integrate indicators of socio-ecological and economic efficiency into energy saving incentive tools in residential and public buildings. In particular, to reimburse investment costs from state, municipal or international funds only for those projects that were identified as optimal according to the ecological, economic, social and technical criteria by means of a multicriteria analysis of the ESM efficiency assessment. In addition, it is necessary to integrate indicators of socio-ecological and economic efficiency into tools of state regulation and quality control of the ESM implementation. The main tendencies of promoting energy saving are defined, which provide continuous training and knowledge dissemination for all key players in the sphere; raising public awareness about reducing negative environmental impacts due to reduced energy consumption. In order to improve the efficiency of the energy management system and reduce energy consumption and emissions of greenhouse gases, it is recommended to improve the energy accounting system, norms of energy consumption and emissions of greenhouse gases.

The application of the proposed recommendations will promote investments in the environmentally- friendly thermo-modernization, bringing us closer to addressing the major challenges facing the world community: achieving the goals of sustainable development and reducing climate instability.

\section{References}

1. Denysyuk, S. (2013). Features of realization of the energy efficiency policypriorities of Ukraine. Power engineering, 7, 7-20.

2. Bennich, T., Belyazid, S., Kopainsky, B., \& Diemer, A. (2018). The bio-based economy: Dynamics governing transition pathways in the Swedish forestry sector. Sustainability (Switzerland), 10(4). https://doi.org/10.3390/su10040976

3. Chevganova, V. \& Petrova, A. (2014). Financing of energy saving projects by using schemes of leasing operations: domestic and foreign experience. Effective Economics, 11. http://www.economy.nayka.com.ua/?op=1\&z=3545

4. Farina, O. (2014). Economic bulletin Pereyaslav-Khmelnytsky Hryhoriy Skovoroda State Pedagogical University. Economic bulletin. Збірник наукових праць, № 23/(1), 156-163. 
5. Fedoruk, M., Zahvoyska, L. (2016). Results of SWOT-analysis of the city Lviv. Supplementing to the Integrated Development Strategy of Lviv 20122025 and to the Program of Sustainable Energy Development of Lviv until 2020, 36-41.

6. Zahvoyska, L. D., Fedoruk, M. I. (2017). Environmental Impact Assessment of Energy Saving Measures in Buildings by SIMAPRO8 Software. Scientific Bulletin of UNFU, 27(7), 14-20. https://doi.org/10.15421/40270702

7. Forrester, J. (1971). Counterintuitive behavior of social systems. Technology Review, 73(3), 52-68.

8. Forrester, J. W. (1992). Policies, decisions and information sources for modeling. European Journal of Operational Research, 59(1), 42-63.

9. GIZ (2010). State support for energy efficiency measures in buildings. Kyiv.

10. Holtz, G., Alkemade, F., De Haan, F., Köhler, J., Trutnevyte, E., Luthe, T., ... Ruutu, S. (2015). Prospects of modelling societal transitions: Position paper of an emerging community. Environmental Innovation and Societal Transitions, 17, 41-58. https://doi.org/10.1016/j.eist.2015.05.006

11. Kopets, H. (2009). Application of financial intermediation mechanisms in implementation of energy saving and energy efficiency projects, 95-97.

12. Lane, D. C. (2008). The emergence and use of diagramming in system dynamics: A critical account. Syst. Res. Behav. Sci., 25(3-23).

13. Meadows, D. H. (2008). Thinking in Systems. A Primer. London: Earthscan.

14. Meadows, D. H., Meadows, D. L., Randers, J., Behrens, W. W. (1972). The limits to growth. New York: Universe books.

15. Minregion. Energy Efficiency Fund concept (2016).

16. Smentyna, N. (2016). State regulation of the energy efficiency in Ukraine: opportunities for population. Scientific Bulletin of the Odessa National Economic University 9, 135-146.

17. Sokolovska, Z., Klepikova, O. (2015). Applied models of system dynamics. Odessa: Astroprint.

18. Stave, K. A., Kopainsky, B. (2015). A system dynamics approach for examining mechanisms and pathways of food supply vulnerability. Journal of Environmental Studies and Sciences, 5(3), 321-336.

19. Sterman, J. D. (2000). Systems Thinking and Modeling for a Complex World. Management (Kd 6). New York: McGraw-Hill. https://doi.org/10.1108/ 13673270210417646

20. Sukhudolya, O. (2015). Strategic Management in the Energy Sector: Problems and Priorities for Improvement. Strategic Priorities, 1, 104-112. 
21. Taukesheva, T. (2015). Mechanisms for Implementing Public Policy in Energy Efficiency and Energy Saving, State regulation of processes of economic and social development, 114-120

22. Titiaev, V., Getalo, H. (2012). Mechanism of activation of investment attractiveness of energy saving in the housing and communal sphere. Municipal economy of cities, 106, 111-123.

23. Tormosov, R. (2010). Comprehensive analysis of sources of financing of municipal energy investment projects in the field of production, transportation and supply of thermal energy. Effective Economics 11. http://www.economy.nayka.com.ua/?op=1\&z=397

24. 24. Van den Belt, M.; Kenyan, J.R.; Krueger, E.; Maynard, A.; Roy, M.G.; Raphael, I. (2010). Public sector administration of ecological economics systems using mediated modeling. Ann. N. Y. Acad. Sci., 1185, 196-210.

25. Videira, N.., Schneider, F.., Sekulova, F.., Kallis, G. (2014). Improving understanding on degrowth pathways: An exploratory study using collaborative causal models. Futures, 55(58-77).

26. Volkov, V. (2014). Problems of energy saving in a housing stock. Economic bulletin Pereyaslav-Khmelnytsky Hryhoriy Skovoroda State Pedagogical University, 83-90. 